\title{
Field survey and comparative biology of tea mosquito bug (Helopeltis spp.) on cashew (Anacardium occidentale Linn.)
}

\author{
Srikumar K. K. ${ }^{1 \star}$ and P. Shivarama Bhat ${ }^{2}$ \\ Department of Entomology, Directorate of Cashew Research, Puttur, Karnataka 574 202, India.
}

Accepted 8 August, 2012

\begin{abstract}
Cashew (Anacardium occidentale Linn.) has become a very important tree crop in India. Several insect pests, however, have been recorded on cashew and prominent among which is the tea mosquito bug (TMB), Helopeltis spp. (Hemiptera: Miridae). Field survey from November 2009 to November 2011 suggests that Helopeltis antonii was dominant, which accounted for $82 \%$ of all Helopeltis spp. collected; whereas, Helopeltis bradyi and Helopeltis theivora accounted for 12 and $6 \%$, respectively. No significant differences in egg hatchability percentage among the three species were observed. The study showed that there is significant variation in developmental rate of $2^{\text {nd }}, 3^{\text {rd }}$ and $4^{\text {th }}$ instar nymphs of Helopeltis spp. The total developmental time for $H$. antonii, $H$. bradyi and $H$. theivora were 224.19, 211.38 and 214.59 hours, respectively. Survival rates of the nymphal instars of $H$. antonii were significantly high compared to $H$. bradyi and $H$. theivora. The sex ratio of $H$. antonii was highly female biased. The adults of $\boldsymbol{H}$. bradyi and H.theivora survived longer and produced significantly higher number of eggs than $\boldsymbol{H}$. antonii. The outcome of this study is very important in planning control as insect monitoring and biological studies are important components of Integrated Pest Management (IPM).
\end{abstract}

Key words: Helopeltis antonii, Helopeltis bradyi, Helopeltis theivora, cashew, relative abundance, developmental rate, survival rate, sex ratio, longevity, fecundity.

\section{INTRODUCTION}

Cashew (Anacardium occidentale L.), a native of Brazil, was introduced in to the West Coast of India by the Portuguese during the sixteenth century (Devasahayam and Nair, 1986). Several insect pests have been recorded on cashew in India (Sundararaju, 1993), prominent among which is the tea mosquito bug (TMB), Helopeltis spp. (Hemiptera: Miridae). The adults and nymphs of TMB damage caused 30 to $50 \%$ yield loss (Abraham and Nair, 1981; Ambika and Abraham, 1984;

*Corresponding author. E-mail: sreeku08@gmail.com. Tel: 08105137220.
Pillaiet et al, 1984). Typical feeding damage by Helopeltis spp. appears as a discoloured necrotic area or a lesion around the point of entry of the labial stylets inside the plant tissue. The infestation of inflorescence results in "blossom blight". Three species of TMB, Helopeltis antonii Signoret, Helopeltis bradyi Waterhouse and Helopeltis theivora Waterhouse (Stonedahl, 1991 and Sundararaju, 1996) were recorded in India. Among them, $H$. antonii is the dominant species (Sundararaju and Bakthavatsalam, 1994). Despite their pest status, Helopeltis spp. attacking cashew has received relatively little research attention in India, and little is known of their species. Earlier $H$. bradyi was not known to occur in the Indian Region, except as established by De Silva (1957) 


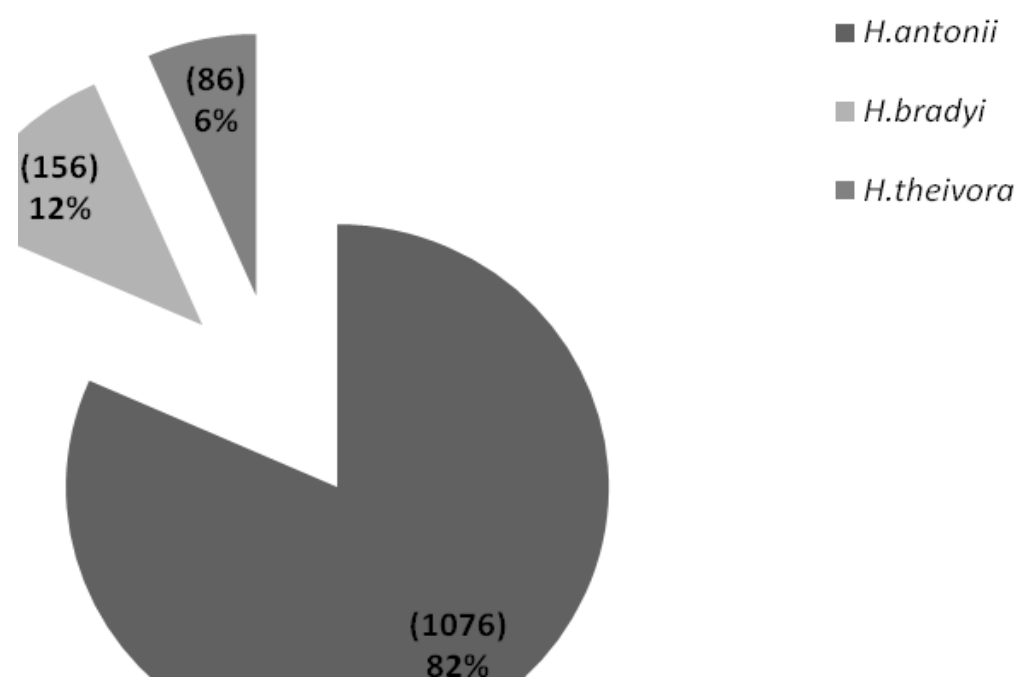

Figure 1. Relative abundance of Helopeltis spp. during the period of study.

under the name $H$. ceylonensis in Sri Lanka. The present investigation was taken up to study the field survey, egg hatchability, nymphal developmental rate, survival rate, sex ratio, adult longevity and fecundity of Helopeltis spp. on cashew in India.

\section{MATERIALS AND METHODS}

All studies of Helopeltis spp. were done from November 2009 to November 2011 on cashew plantations at the Directorate of Cashew Research (DCR), Puttur, Karnataka, India and Experimental station, Shanthigodu $\left(12.45^{\circ} \mathrm{N}\right.$ latitude, $75.4^{\circ} \mathrm{E}$ longitude and $90 \mathrm{~m}$ above MSL). Identification of Helopeltis was carried out according to Stonedahl (1991).

The number of nymphs and adults of Helopeltis spp. found were isolated, recorded and reared in laboratory conditions for further study. The samples were collected randomly though out the period of study.

\section{Laboratory culture of Helopeltis spp.}

The Helopeltis spp. females collected using long test tubes were allowed to lay eggs on potted cashew seedlings in the laboratory. The seedlings were enclosed in perforated tubular transparent polyester film (thickness 175 Micron and cage size $30 \times 7.5 \mathrm{~cm}$ ), and watered daily with $30 \mathrm{ml}$ of water to avoid wilting. The respiratory processes of eggs projecting from the surface of the bark were indicative of the presence of eggs. Immediately after hatching, the nymphs of each species were transferred into nymphal rearing cages (size: $15 \times 15 \times 20 \mathrm{~cm}$ and thickness: 18 gauge) developed by Sundararaju and John (1992) were done from fifth to seventh day after oviposition to prevent nymphal migration. Nymphal rearing cages consisted of four glass vials of $5 \mathrm{ml}$ capacity fixed on a small aluminum stand with a handle of $15 \mathrm{~cm}$ height fixed at the centre. In the rearing cage, two side provisions were made on with cloth sleeve in order to facilitate the removal of adults after final moulting.
The eggs laden on seedlings were maintained in laboratory at labeled, dated and daily observed until hatch. The hatchability was calculated using the following formula:

Egg hatchability $=\frac{\text { Total no. of nymphs emerged }}{\text { Total no. of eggs laid }} \times 100$

Twenty newly hatched nymphs of Helopeltis spp. (less than $24 \mathrm{~h}$ ) were transferred individually into each nymphal rearing cage. The new hatched nymphs were fed on fresh cashew shoots kept in water filled vial for two days. The nymphs were observed daily to notice and record the moult of each instar. The cast skin was removed with fine camel hair brush immediately after each moult to avoid the mixing with previous cast skin. The period from instar to instar and from nymphal stage to adult emergence were recorded for each species.

Survival rates of Helopeltis spp. were calculated by reducing the death of each instar and adults during developmental times. Newly emerged males and females from laboratory were mated in a sleeve cage on flushing shoots in the field. The oviposition, adult death, longevity and number of eggs were recorded each $48 \mathrm{~h}$. The sex ratio was calculated using the number of adults that emerged from three replicates (each replicate includes twenty nymphs).

Monthly rainfall, temperature and relative humidity in the cashew plantation at Puttur were monitored throughout the experiments. All experiments were designed as completely randomized design (CRD) with three replicates using Analysis of Variance (ANOVA). The data were analyzed using F- test.

\section{RESULTS}

During the study period, temperature in the field ranged from 17.5 to $38^{\circ} \mathrm{C}$, humidity (39 to $97 \%$ ), monthly rainfall (0 to $1149 \mathrm{~mm}$ ) and sunshine hours is 1.2 to $9.2 \mathrm{~h}$.

Among the three species studied, $H$. antonii was dominant, which accounted for $82 \%$ of all Helopeltis spp. Collected; whereas, $H$. bradyi and $H$. theivora accounted 


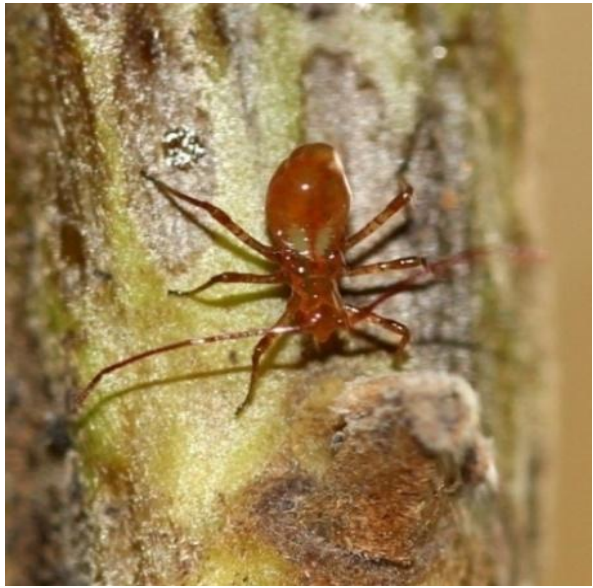

Figure 2. Helopeltis antonii $3^{\text {rd }}$ instar nymph.

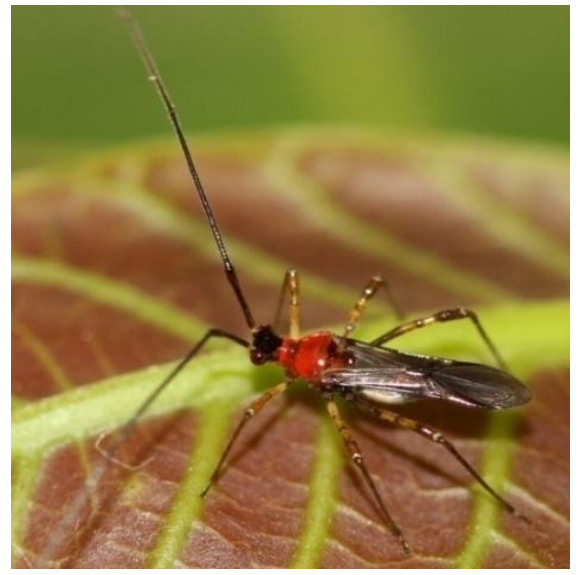

Figure 3. Helopeltis antonii adult.

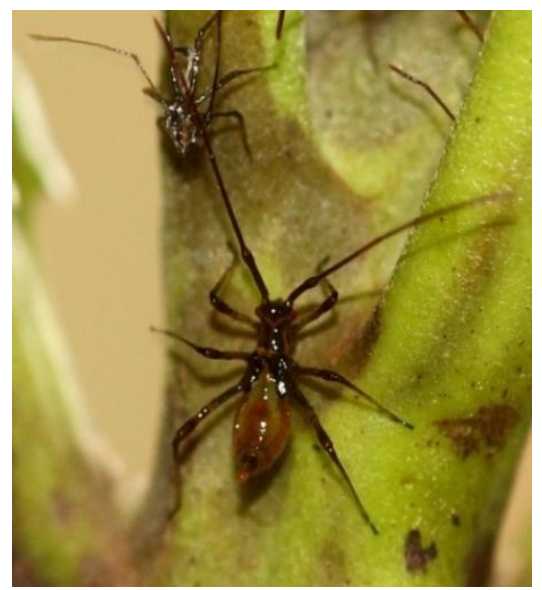

Figure 4. Helopeltis bradyi $3^{\text {rd }}$ instar nymph.

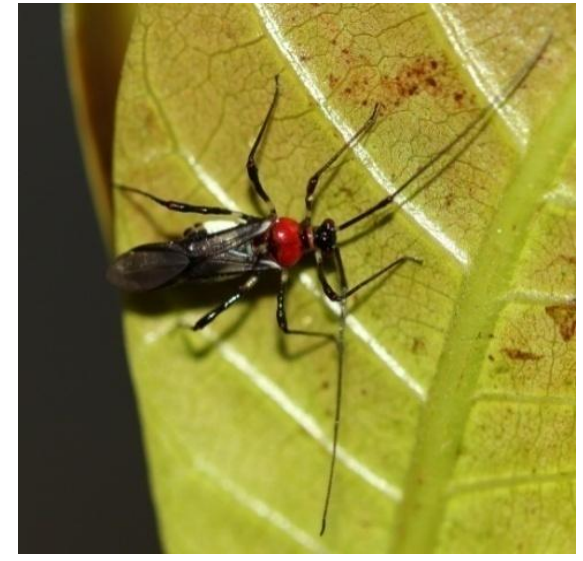

Figure 5. Helopeltis bradyi adult.

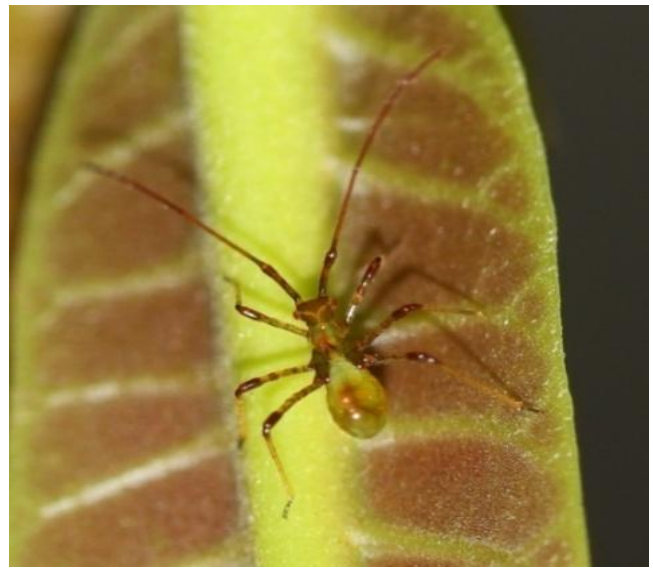

Figure 6. Helopeltis theivora $3^{\text {rd }}$ instar nymph.

for 12 and $6 \%$ (Figure 1), respectively.

The Helopeltis species can be morphologically differentiated of $H$. antonii are reddish orange in colour (Figure 2); whereas, they are light brown in $\mathrm{H}$. bradyi (Figure 4) and slight greenish in $H$. theivora (Figure 6). Adults of Helopeltis spp. collected from the field were identified by using the keys (Stonedahl, 1991) as $H$. antonii (Figure 3), $H$. bradyi (Figure 5 ) and $H$. theivora (Figure 7 ). $H$. antonii shows less morphological variation with $H$. bradyi than $H$. theivora. The description of leg coloration, particularly the hind femora without a pale annulus basally, clearly distinguishes Signoret's $H$. antonii from the externally similar species $H$. bradyi.

There were no significant differences in egg hatchability percentage among the three species. The mean \% hatchability was $65 \pm 8.20,64 \pm 6.81$ and $66 \pm 9.79$ for $H$. antonii, $H$. bradyi and $H$. theivora respectively (Table 1 ). The developmental period of $1^{\text {st }}$ instar nymphs of $H$. antonii, H.bradyi and H.theivora were statistically on par. 


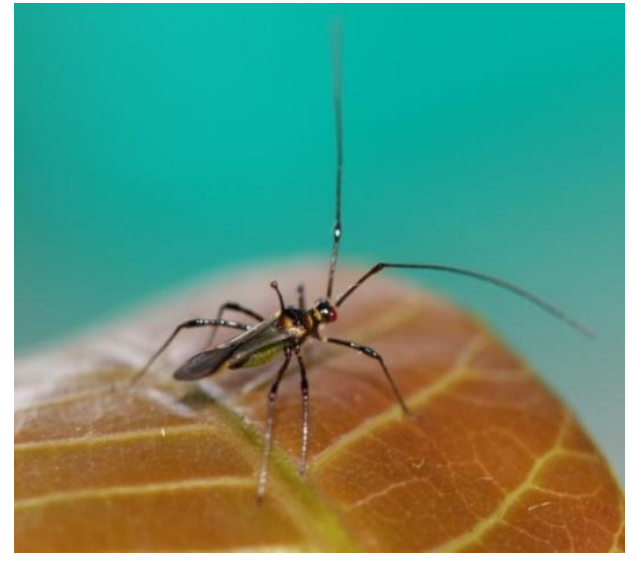

Figure 7. Helopeltis theivora adult.

Table 1. Percent egg hatchability of Helopeltis spp.

\begin{tabular}{lc}
\hline Helopeltis spp. & Percent egg hatchability (mean \pm S.D) \\
\hline H. antonii & $65 \pm 8.20(105)$ \\
H. bradyi & $64 \pm 6.81(106)$ \\
H. theivora & $66 \pm 9.79(102)$ \\
CD $(P=0.05)$ & N.S \\
\hline
\end{tabular}

$\mathrm{N} . \mathrm{S}=$ Non significant.

The developmental time of $2^{\text {nd }}$ instar was significantly $(P=$ 0.05 ) higher for $H$. antonii, that is, $36.72 \mathrm{~h}$, while it was from $3^{\text {rd }}$ instar nymphal stage. The nymphs 28.22 and $26.39 \mathrm{~h}$ for $H$. theivora and $H$. bradyi, respectively. The developmental period of $3^{\text {rd }}$ instar was significantly $(P=$ $0.05)$ faster for $H$. bradyi compared to $H$. theivora and $H$.antonii. Whereas, the fourth instar developmental period was longer for $H$. bradyi $(42.11 \mathrm{~h})$ followed by $H$. theivora $(39.03 \mathrm{~h})$. The $4^{\text {th }}$ instars of $H$. antonii developmental time was significantly $(P=0.05)$ faster, that is, $8.86 \mathrm{~h}$ less than $H$. bradyi and $3.08 \mathrm{~h}$ less than $H$. theivora (Table 2).

The $5^{\text {th }}$ instar of $H$. theivora took $70.23 \mathrm{~h}$ for development which was the longest period followed by $H$. antonii which emerged in $69.9 \mathrm{~h}$ while the lowest period was observed in case of $H$. bradyi which emerged in $66.73 \mathrm{~h}$. The total developmental period for $H$. antonii, $H$. bradyi and $H$. theivora were 224.19, 211.38 and $214.59 \mathrm{~h}$, respectively. The developmental time of $H$. antonii recorded significant $(P=0.05)$, differences compared to $H$. theivora and $H$. antonii.

As shown in Table 3, the number of nymphs survived in all the nymphal stages were significantly $(P=0.05)$ higher for $H$. antonii compared to $H$. bradyi and $H$. theviora. The percent survival was maximum (>90\%) for $H$. antonii in all the five instars compared to other two species. The percent survival of $1^{\text {st }}$ and $2^{\text {nd }}$ instar were significantly higher $(P=0.05)$ for $H$. antonii, whereas, for $H$. bradyi and $H$. theivora it was statistically on par. The survival percentage of $3^{\text {rd }}$ instar nymphs of $H$. antonii and $H$. bradyi were significantly $(P=0.05)$ higher compared to $H$. theivora. The $4^{\text {th }}$ instar survival was significantly $(P=$ 0.05 ) higher for $H$. antonii, that is, $94.45 \%$, while it was 83.33 and $64.58 \%$ for $H$. bradyi and $H$. theivora, respectively. Finally, $91.67 \%$ of nymphs reached adult stage in $H$. antonii, whereas, only 66.67 and $64.58 \%$ in $H$. bradyi and $H$. theivora, respectively.

In the three species of Helopeltis, the female sex ratio was higher for H.antonii than H.bradyi and H.theivora, that is, 1: 3.76 , while it was $1: 1.27$ and $1: 1.17$ for $H$. bradyi and $H$. theivora, respectively (Table 4).

There was a distinct difference in the longevity of both the sexes of all Helopeltis spp. as shown in Table 5. The females generally lived longer than males of all species of Helopeltis. The longevity of $H$. antonii male was significantly $(P=0.05)$ lower compared to that of $H$. bradyi and $H$. theivora. $H$. bradyi males lived up to $24 \pm$ 0.63 days, whereas, $H$. theivora and $H$. antonii males survived for $23.17 \pm 1.94$ and $19.5 \pm 3.15$ days, respecttively. Similarly, female longevity was also significantly $(P$ $=0.05$ ) lower in $H$. antonii (22.83 \pm 2.14 days) followed by $H$. theivora (24.67 \pm 1.63 days) and $H$. bradyi $(26.33 \pm$ 1.51 days). Among the three species, mean fecundity was higher for $H$. bradyi (140.33 \pm 25.73 eggs) followed by $H$. theivora (131 \pm 37.82 eggs) and was significantly $(P=0.05)$ least in $H$. antonii which recorded only $94.83 \pm$ 5.85 eggs/female.

\section{DISCUSSION}

The pest survey revealed that three species of tea mosquito bug were infesting cashew viz., $H$. antonii, $H$. bradyi and $H$. theivora, and among them $H$. antonii was the most dominant and prolific species on cashew during the period of study. Among the three species studied, $\mathrm{H}$. antonii was dominant, which accounted for $82 \%$ of all Helopeltis spp. collected, whereas, $H$. bradyi and $H$. theivora accounted 12 and $6 \%$, respectively. The study is in agreement with earlier reports which mentioned $H$. antonii as the most serious pests of cashew in all cashew growing regions of India (Ambika and Abraham, 1979, Devasashayam et.al., 1986 and Sundararaju et.al., 1999). The coexistence of $H$. theivora and $H$. bradyi with $H$. antonii was earlier found in the west coast of India (Sundararaju and Sundarababu, 1999) and in few other parts of India (Ambika and Abraham, 1984).

The developmental rate of $H$. antonii nymphs was comparatively slower than that of $H$. bradyi and $H$. theivora. The mean nymphal developmental time for $H$. antonii, $H$. bradyi and $H$. theivora were 9.34, 8.81 and 8.94 days, respectively (Table 2 ) during the study period. 
Table 2. Mean nymphal developmental period of Helopeltis spp.

\begin{tabular}{lcccccc}
\hline \multirow{2}{*}{ Helopeltis spp. } & \multicolumn{6}{c}{ Mean development period (hours) } \\
\cline { 2 - 7 } & $\mathbf{1}^{\text {st }}$ instar & $\mathbf{2}^{\text {nd }}$ instar & $\mathbf{3}^{\text {rd }}$ instar & $\mathbf{4}^{\text {th }}$ instar & $\mathbf{5}^{\text {th }}$ instar & Total \\
\hline H. antonii & $43.62^{\mathrm{a}}$ & $36.72^{\mathrm{a}}$ & $40.7^{\mathrm{a}}$ & $33.25^{\mathrm{b}}$ & $69.9^{\mathrm{a}}$ & $224.19^{\mathrm{a}}(9.34)$ \\
H. bradyi & $43.01^{\mathrm{a}}$ & $26.39^{\mathrm{b}}$ & $33.14^{\mathrm{b}}$ & $42.11^{\mathrm{a}}$ & $66.73^{\mathrm{a}}$ & $211.38^{\mathrm{b}}(8.81)$ \\
H. theivora & $42.28^{\mathrm{a}}$ & $28.22^{\mathrm{b}}$ & $34.83^{\mathrm{a}}$ & $39.03^{\mathrm{a}}$ & $70.23^{\mathrm{a}}$ & $214.59^{\mathrm{b}}(8.94)$ \\
SE & 0.92 & 1.34 & 4.77 & 2.46 & 2.41 & 8.19 \\
$\mathrm{CD}(P=0.05)$ & $\mathrm{N} . \mathrm{S}$ & 3.48 & 6.41 & 4.60 & $\mathrm{~N} . \mathrm{S}$ & 8.39 \\
CV & 7.75 & 13.16 & 21.56 & 14.26 & 7.80 & 4.60 \\
\hline
\end{tabular}

In a column, values followed common letters do not significantly differ at $P=0.05$; N.S $=$ Not significant; Figures in the parentheses indicate the duration in days.

Table 3. Mean percentage survival of Helopeltis spp.

\begin{tabular}{lcccccc}
\hline \multirow{2}{*}{ Helopeltis spp. } & \multicolumn{7}{c}{ Mean percent survival } \\
\cline { 2 - 7 } & $\mathbf{1}^{\text {st }}$ instar & $\mathbf{2}^{\text {nd }}$ instar & $\mathbf{3}^{\text {rd }}$ instar & $\mathbf{4}^{\text {th }}$ instar & $\mathbf{5}^{\text {th }}$ instar & Adult \\
\hline H. antonii & $94.45^{\mathrm{a}}$ & $94.45^{\mathrm{a}}$ & $91.67^{\mathrm{a}}$ & $94.45^{\mathrm{a}}$ & $91.67^{\mathrm{a}}$ & $86.12^{\mathrm{a}}$ \\
H. bradyi & $63.34^{\mathrm{b}}$ & $65.42^{\mathrm{b}}$ & $87.50^{\mathrm{a}}$ & $83.33^{\mathrm{b}}$ & $66.67^{\mathrm{b}}$ & $64.59^{\mathrm{b}}$ \\
H. theivora & $64.42^{\mathrm{b}}$ & $64.58^{\mathrm{b}}$ & $70.83^{\mathrm{b}}$ & $64.58^{\mathrm{b}}$ & $64.58^{\mathrm{b}}$ & $62.50^{\mathrm{b}}$ \\
SE & 13.31 & 8.65 & 9.01 & 10.02 & 3.38 & 10.38 \\
CD $(P=0.05)$ & 12.62 & 10.17 & 10.38 & 10.95 & 6.36 & 11.12 \\
CV \% & 9.81 & 7.86 & 7.20 & 7.84 & 4.95 & 9.04 \\
\hline
\end{tabular}

In a column, values followed common letters do not significantly differ at $P=0.05$.

Table 4. The sex ratio of Helopeltis spp.

\begin{tabular}{lcc}
\hline \multirow{2}{*}{ Helopeltis spp. } & \multicolumn{2}{c}{ Sex ratio } \\
\cline { 2 - 3 } & Male & Female \\
\hline H. antonii & 1.00 & 3.76 \\
H. bradyi & 1.00 & 1.27 \\
H. theivora & 1.00 & 1.17 \\
\hline
\end{tabular}

But, most reported nymphal life spans of $H$. antonii (first instar through fifth instar) are in the range of 9 to 19 days (Ambika and Abraham, 1979; Devasahayam, 1986) and $H$. bradyi was 27 to 43 days on tea in the Cameroon Highlands (Lever, 1949). This may be due to difference in climatic conditions and quality of the food source as referred by Betrem (1953), Wang et al. (1988), Khoo and Chung, (1989). In the present investigation, the nymphal developmental period was found to vary for the instars of all three Helopeltis spp. These results are comparable to Khan and Quade (2008), who reported a difference in mean development time (days) among the instars of mirid bugs viz., Creontiades dilutes and Creontiades pacificus, which are pests of cotton. It was observed in the present work that the $5^{\text {th }}$ instar nymphal life span was highest for Helopeltis spp. This is in accordance with Smith (1979), who recorded longest development period of fifth instar for Helopeltis clavifer.

In the present study, the survival rates was significantly $(P=0.05)$ higher for $H$. antonii than $H$. bradyi and $H$. theivora. This higher nymphal survival rate might have facilitated $H$. antonii to turn out to be more prevalent species on cashew. So far, there is no appropriate report on nymphal survival rates of $H$. bradyi and $H$. theivora on cashew. The nymphal survival rate was found to be $64.59 \%$ for $H$. bradyi and $62.5 \%$ for $H$. theivora. This result is quite comparable with the study of Somnath et al. (2009), who recorded 66.6 to $70.6 \%$ of survival of $H$. theivora nymphs on tea.

Sex ratio of a population plays an important role in determining the rate of increase of a population. In the present study, it was found that the male female sex ratio was 1: $3.76,1: 1.27$ and $1: 1.17$ for $H$. antonii, $H$. bradyi and $H$. theivora respectively for cashew reared insects. This is in support with Ambika and Abraham (1979), who also reported the female dominance in $H$. antonii in India. Besides, Phistikul and Chayopas (1997) also mentioned that female and male sex ratio of $H$. theivora was 1.0:2.2 on cashew. The present investigation demonstrated that $H$. antonii had higher female sex ratio over $H$. bradyi and $H$. theivora.

This higher female sex ratio might also facilitated $H$. 
Table 5. Mean longevity and fecundity of Helopeltis spp.

\begin{tabular}{lccl}
\hline \multirow{2}{*}{ Helopeltis spp. } & \multicolumn{2}{c}{ Longevity (days) } & \multirow{2}{*}{ Fecundity (Mean \pm S.D) } \\
\cline { 2 - 4 } & Male (Mean \pm S.D) & Female (Mean \pm S.D) & \\
\hline H. antonii & $19.50 \pm 3.15^{\mathrm{a}}$ & $22.83 \pm 2.14^{\mathrm{a}}$ & $94.83 \pm 5.85^{\mathrm{a}}$ \\
H. bradyi & $24.00 \pm 0.63^{\mathrm{b}}$ & $26.33 \pm 1.51^{\mathrm{b}}$ & $140.33 \pm 25.73^{\mathrm{b}}$ \\
H. theivora & $23.17 \pm 1.94^{\mathrm{b}}$ & $24.67 \pm 1.63^{\mathrm{b}}$ & $131.00 \pm 37.82^{\mathrm{b}}$ \\
SE & 0.94 & 0.38 & 112.13 \\
CD $(P=0.05)$ & 3.06 & 1.93 & 33.37 \\
CV \% & 10.70 & 6.10 & 21.25 \\
\hline
\end{tabular}

In a column, values followed common letters do not significantly differ at $P=0.05$.

antonii to multiply its population rapidly and dominate on cashew. The present investigation depicted $H$. bradyi with higher fecundity $(140.33 \pm 25.73)$ followed by $H$. theivora $(131.00 \pm 37.82)$ and $H$. antonii $(94.83 \pm 5.85)$. These results are comparable to Sundararaju and Sundara (1998, 1999) and Devasahayam (1986), who recorded that fecundity of $H$. antonii can reach up to 128.1 eggs per female and found to be seasonally variable from 13 to 82 eggs per female.

The adult longevity of Helopeltis spp. varied from 19.50 \pm 3.15 to $26.33 \pm 1.51$ days. Stonedahl (1991) and Sundararaju (1996) reported that longevity of Helopeltis spp. can vary from 7 to 46 days. According to Songyot and Punpen (1997), longevity of female and male $H$. theivora on cashew was 36.8 and 33.6 days, respecttively. The present study is in agreement that female longevity is generally longer than male.

\section{Conclusion}

Field survey of Helopeltis spp. depicted that $H$. antonii was dominant among the three species found in cashew. The rate of development of nymphal instars showed variation among Helopeltis spp. The survival rate of $H$. antonii was significantly higher than $H$. bradyi and $H$. theivora, whereas, the fecundity and longevity was significantly higher for $H$. bradyi and $H$. theivora. The sex ratio of $H$. antonii was heavily female biased. The higher survival rate and female sex ratio might have helped $H$. antonii to establish its population higher than $H$. bradyi and $H$. theivora. The outcome of this study can aid in planning control as insect monitoring, and biological studies are important components of Integrated Pest Management (IPM).

\section{ACKNOWLEDGEMENTS}

The authors greatly acknowledge the Indian Council of Agricultural Research Network Project on Management of Sucking Pests for providing all financial support to carry out the work. We are also thankful to the Director, Directorate of Cashew Research, Puttur for providing necessary facilities.

\section{REFERENCES}

Abraham CC, Nair GM (1981). Effective management of the tea mosquito bugs for breaking the yield barriers in cashew. Cashew Causerie 3(1):6-7.

Ambika B, Abraham CC (1979). Bioecology of Helopeltis antonii Sign. (Miridae: Hemiptera) infesting cashew trees. Entomon. India 4:335342.

Ambika B, Abraham CC (1984). Effect of tropical application of $\mathrm{JH}$ analogue on the developement and survival of the cashew mirid bug Helopeltis antonii Sign . (Miridae: Heteropetera). Cashew Research and Development. Indian Society for Plantation crops, CPCRI. Kasargod, India. pp.111-115.

Awang A, Muhamad R, Chong KK (1988). Comparative merits of cocoa pod and shoot as food sources of the mirid Helopeltis theobromae Miller. Planter. 64:100-104.

Betrem JG (1953). The control of the mosquito blight on cocoa in Java. Proceedings of the Eighth International Congress of Entomology, Stockholm 1948:593-596

De Silva MD (1957). A new species of Helopeltis (HemipteraHeteroptera, Miridae) found in Ceylon. Bull. Entomol. Res. 48:459461.

Devasahayam S, Nair CPR (1986). The mosquito bug, Helopeltis antonii Sign. on cashew in India. J. Plant. Crops 14:1-10.

Khan M, Quade A (2008). QDPI \& F and Cotton Catchment Communities Cooperative Research Centre, Kingaroy, Qld p. 4610.

Khoo KC, Chung GF (1989). Use of the black cacao ant to control mirid damage in Cocoa. Planter. 65:370-383.

Lever RJAW (1949). The tea mosquito bugs (Helopeltis spp.) in the Cameron Highlands. Malayan Agric. J. 32:91-108.

Pillai GB, Singh V, Dubey OP, Abraham VA (1984). Seasonal abundance of tea mosquito bug, Helopeltis antonii on cashew in relation to meteorological factors. In: Cashew research and development, Indian Society for Plantation Crops, CPCRI, Kasaragod, India, pp.103-110.

Smith ESC (1979). Descriptions of the immature and adult stages of the cocoa mirid Helopeltis clavifer (Heteroptera: Miridae). Pac. Insects 20(4):354-361.

Somnath R, Gurusubramanian G, Ananda M (2009). Variation of resistance to endosulfan in tea mosquito bug, Helopeltis theivora Waterhouse (Heteroptera: Miridae) in the tea plantation of the SubHimalayan Dooars, northern west Bengal, Indian J. Bacteriol. Res. 1(3):029-035.

Songyot P, Punpen C (1997). Biology of mosquito bug, Helopeltis theivora Waterhouse, an insect pest of cashewnut. Khon Kaen Agric. J. 25(3):132-138. 
Stonedahl GM (1991). The Oriental species of Helopeltis (Heteropetera: Miridae): a review of economic literature and guide to identification. Bull. Entomol. Res. 81:465-490.

Sundararaju D (1993). Compilation of recently recorded and some new pests of cashew in India. Cashew 8(1):15-19.

Sundararaju D (1996). Studies on Helopeltis spp. with special reference to H.antonii Sign. in Tamil Nadu.Ph.D. thesis. T.N. A.U., Coimbatore, India.

Sundararaju D, Bakthavatsalam NN (1994). Advances in Horticulture (Eds). Chadha K.L. and Rethinam P., Malhotra Publishing House, New Delhi. 10:759-785.

Sundararaju D, John NJ (1992). Mass rearing technique for Helopeltis antonii Sign. (Heteroptera: Miridae) - An Important pest of cashew. J. Plant Crops 20(1):46-53.
Sundararaju D, Sundara BPC (1998). Life table studies of Helopeltis antonii Sign. (Heteroptera: Miridae) on neem, guava and cashew. J. Entomol. Res. 22 (3): 241-244.

Sundararaju D, Sundarababu PC (1999). Helopeltis spp. (Heteroptera: Miridae) and their management in plantation and horticultural crops of India. J. Plant. Crops 27(3):155-174. 